\title{
Sun-glitter Photographs of Georges BANK AND THE Gulf OF MAINE FROM THE Space ShuttLe
}

\author{
By Paul E. La Violette, Donald R. Johnson and David A. Brooks
}

\begin{abstract}
A INYONE WHO HAS FLOWN over open water and noticed sunlight glittering from the water surface has probably been intrigued by the richness of the patterns seen in the sun's reflectance. A number of investigators have explored the reflection phenomenon for the purpose of extracting information about surface waves, internal waves and a variety of frontal features associated with water masses and currents (e.g., Cox and Munk, 1954; Soules, 1970; Strong and De Rycke. 1973; La Violette, et al., 1980 and Gasparovic, et al., 1985). Since the ocean`s surface is not smooth, the sun's reflectance does not appear as a disk, as in a mirrored reflection, but as a vagueedged image whose distortion is determined by the solar incident angle and the amount of small-scale ocean roughness. The resulting sun glitter accentuates the spatial patterns associated with small-scale roughness that are mainly caused by spatial variations in wind stress, waves and wave-current interactions. The observed patterns are associated with oceanic processes and, when viewed from high altitudes. they can be used to identify the location of these processes over relatively large ocean areas.
\end{abstract}

Photographs of the oceans taken from the U.S. space shuttles have provided the most striking examples of sun-glitter patterns. Taken from an altitude of approximately $300 \mathrm{~km}$, shuttle photographs give both adequate spatial resolution and areal coverage for regional studies of meso- and submeso-scale phenomena. Such photographs have been used in a number of ocean studies, where they have contributed spatial information difficult to obtain by other methods (Osborne and Burch. 1980; Apel, et al., 1985: La Violette and Arnone, 1988). Although shuttle photographs are difficult to navigate, limited in temporal resolution, and often serendipitous, they can provide regional overviews of startling detail.

To illustrate, we show in Fig. 1 (p. 44-45) two sequential shuttle photographs taken during the STS-28 flight of Columbia in August 1989. The photographs.

Paul E. La Violette and Donald R. Johnson. Naval Oceanographic and Atmospheric Research Laboratory. Code 321, Stennis Space Center, MS 39521: David A. Brooks, Department of Oceanography, Texas A\&M University, College Station, TX 77843-3146. taken within seconds of each other, show afternoon sunlight reflecting from the water surface off the northeast coast of the US, in the region of Georges Bank and the southern Gulf of Maine. As the shuttle moves, the sun's reflection on the ocean surface (as seen from the shuttle) also moves. This produces a sweeping effect, as if the sun glitter were a spotlight that illuminates a portion of the ocean below, enhancing features on the ocean surface as it moves.

In this paper we review basic aspects of sun glitter and point out several interesting oceanic phenomena evident in the sun-glitter patterns seen in the two shuttle photographs. Our purpose here is to illustrate the unique opportunity for ocean research afforded by shuttle photography, rather than to offer detailed analyses of the phenomena.

\section{Sun Glitter From the Sea Surface}

Sun glitter from the sea surface is the mirror-like return obtained when sunlight is directly reflected into the field of view. If the sea surface were calm, then only the portion producing the solar reflection would appear bright: the sea surface every where else would appear relatively dark. In contrast. when smallscale roughness appears on the sea surface, the amount of light reflected into the field of view is diffused, and the area of brightness is enlarged by wave facets that produce reflections from many different angles. An area of calm sea, embedded in a larger area of roughened sea, will appear successively dark, then bright, and then dark again as the viewing angle with respect to the sun changes.

Interpretation of sun-glitter patterns on the sea surface and their relationship to oceanographic phenomena requires an understanding of the physical processes that create smooth and roughened waters. For example. surface wind stresses and wave-current interactions can generate sharp horizontal changes in small-scale surface roughness. Physico-chemical properties of the surface, resulting from organic surface "slicks." can modulate the resulting surface roughness.

On a calm day, capillary waves called "cats' paws" appear under turbulent wind gusts. The affected areas give the surface reflectance a patchiness of light and dark and provide a unique means of 


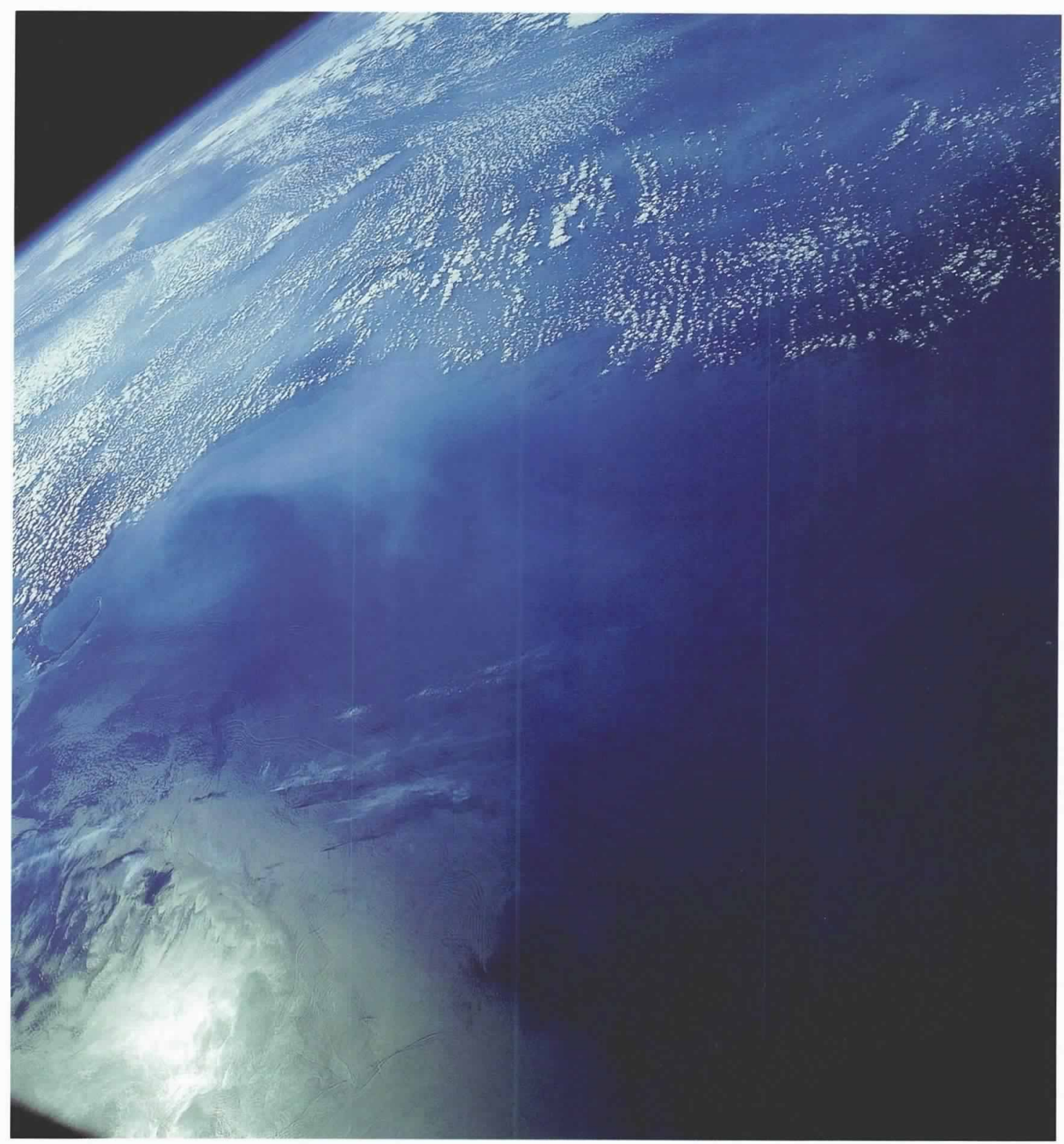

Fig. 1a: An expanded section of the shuttle photograph featured on the cover. The view is from an altitude of about $300 \mathrm{~km}$, looking toward the west-southwest (part of the shuttle ground track is shown in Fig. 2,p. 47). The sun-glitter patterns reveal detailed surface expressions of several physical features. The dark region in the lower left quadrant of the figure outlines cold, tidally-mixed water found over the shallow top of Georges Bank (cf. Fig. 2). Also seen are several packets of tidally-forced internal waves propagating away from the northern edge of the bank into the stratified waters of the Gulf of Maine. The wispy swirl of lighter blue adjacent to the coast in the top central part of the figure apparently identifies cool surface coastal waters moving southwestward as part of the interior circulation in the gulf. All of these features are suggested in the visual photographs because the small-scale surface roughness that scatters the sunlight is affected by the features, as explained in the accompanying text. (From NASA photograph number STS 28-151-216.)

estimating spatial scales important in the initial growth rate of wave spectra. On a larger scale, abrupt wind stress changes associated with atmospheric storms and fronts create obvious gradients of surface roughness.

Previous studies (e.g., Arya, 1975) have demonstrated that the stress of the wind on the ocean surface markedly depends on the thermal stability of the air immediately above the surface. If the sea is cooler than the air above it, the atmospheric boundary layer loses heat to the ocean and becomes dynamically stable. This tends to inhibit the downward turbulent flux of momentum in the boundary layer, which in turn reduces the effective drag coefficient (i.e., the ability of the wind to push the water). Thus, as air flows from over a warm sea to over a cool sea, the surface stress is diminished and the degree of smallscale surface roughness is reduced. The reverse is also true, with the effect in both directions most noticeable when the winds are light. This thermal 


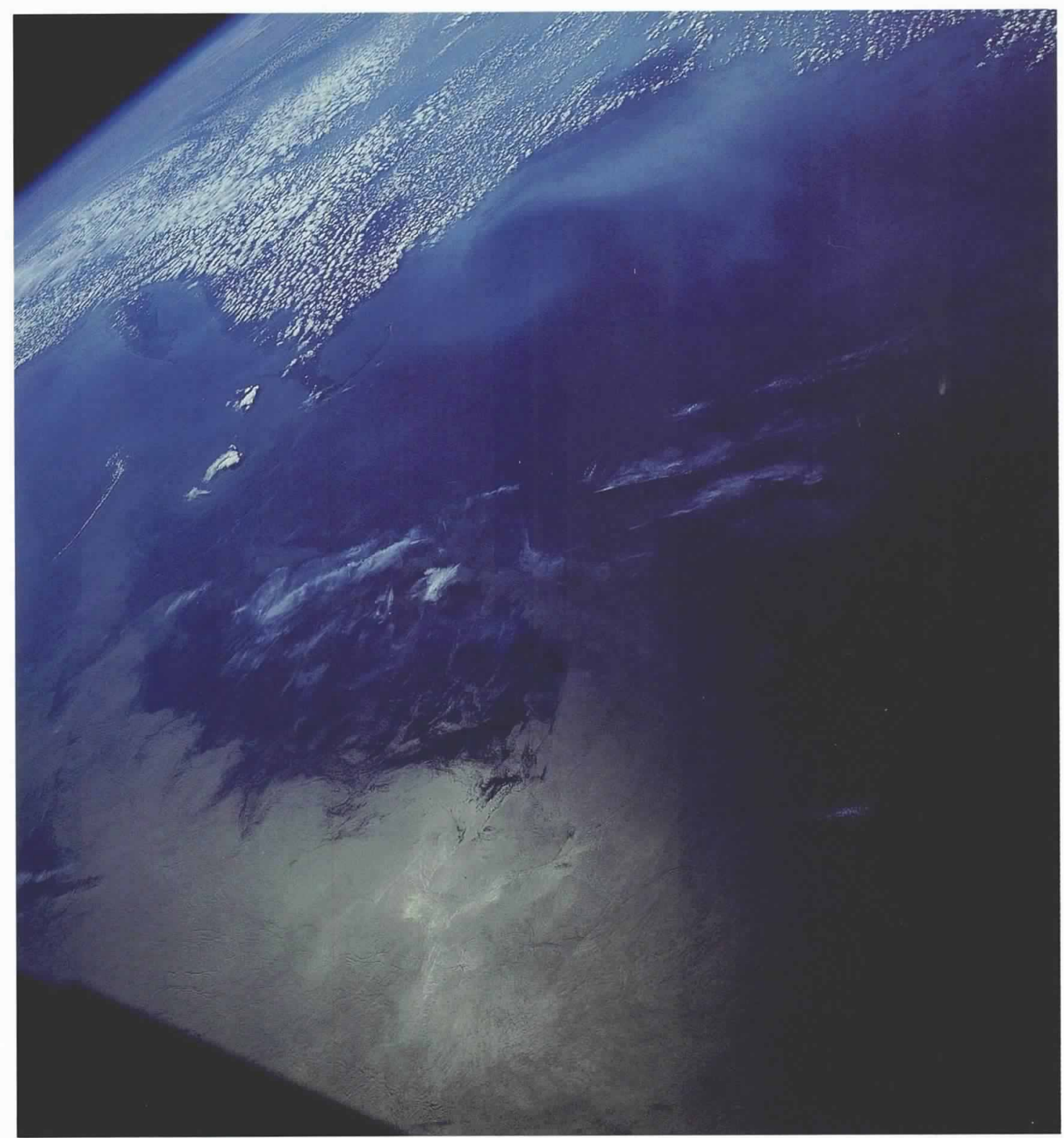

Fig. 1b: An excerpt from a companion shuttle photograph taken a few seconds later than the one shown in Fig. 1a. The shuttle has moved southeastward along its ground track (cf. Fig. 2) and the sun's glitter pattern has correspondingly moved offshore, highlighting the seaward edge of Georges Bank. In the later photograph, the internal waves are hardly noticeable, but perturbations of the tidal front along the bank's southern side are dramatically outlined. The pattern of extrusions of cold water from atop the bank resembles the topographic structure of some of the canyons that incise the outer shelf. In both figures, bright white clouds cover the mainland and identify the islands of Martha's Vineyard and Nantucket; several cloud rows or 'streets' drift over the bank into the gulf. The hook-shaped cloud south of Nantucket appears to be associated with the inner edge of a warm-core ring from the Gulf Stream (cf. Fig.3, p. 48). (From NASA photograph STS 28-151-217.)

effect has been observed at the shoreward Gulf Stream boundary (Weissman et al., 1980), where horizontal sea surface temperature gradients are strong. The resulting roughness changes have often been used to locate the boundary between the warm Gulf Stream and the cooler shelf waters.

Wind stress appears to be the fundamental cause of surface roughness. However, wave-current interactions and surfactant films modify and redistribute the wind-generated small-scale wave fields. The compression of surfactants into long, linear slicks by convergent currents associated with shallow internal waves and Langmuir cells is well known. The dampening of small scale roughness by surface films provides a visual display of the horizontal scales associated with the phenomena.

Blockage of wavelets by convergent or sheared currents in tidal inlets and shallow areas with rapidly changing bathymetry often provides visual linear boundaries between roughened water (where the 
The shuttle

photographs reveal an

irregular set of cool

water extrusions or

tendrils projecting

seaward into the shelf

water on the Atlantic

side of the bank. blocked wave energy accumulates) and calmer water downwind from the boundary. Strong horizontal current shear can sometimes be detected by the refraction patterns of swell and the concomitant redistribution of wave energy.

\section{Georges Bank}

The Gulf of Maine is a semi-enclosed sea nearly cut off from the Atlantic Ocean by Georges Bank (Fig. 2). The Northeast Channel, with a sill depth of $235 \mathrm{~m}$, divides Georges Bank from the Scotian Shelf and provides the major deep connection between the gulf and the Atlantic waters. A shallower and less significant connection is provided by the Great South Channel, which divides the bank from Nantucket Shoals and Cape Cod.

The waters of the gulf and its adjoining Bay of Fundy experience a nearly resonant semi-daily tide, which produces tidal currents approaching $1 \mathrm{~m} \mathrm{~s}^{-1}$ over the shoal areas of Georges Bank and the southwestern Scotian Shelf (Garrett, 1972). The strong tidal currents cause vertical mixing that results in nearly isothermal conditions on the bank, with summer water temperatures of $14-15{ }^{\circ} \mathrm{C}$ typically found inside the $50 \mathrm{~m}$ isobath (Flagg, 1987). A shelfedge front separates the tidally-mixed region on top of the bank from stratified waters typically found beyond the $50 \mathrm{~m}$ isobath. A clockwise flow around the edge of the bank is associated with the baroclinic structure of the shelf-edge front (Butman et al., 1987) and also with non-linear rectification of the tidal currents (Loder, 1980). Excellent reviews of the processes affecting Georges Bank are given by Backus (1987).

The relatively cool temperature of the well-mixed water atop the bank is often seen in thermal infrared images taken from satellites. For example, Fig. 3 (p. 48) shows an infrared image from the same day as the shuttle photographs. The darker blues in the figure generally outline the shallow top of the bank by revealing the cold surface waters within the $50 \mathrm{~m}$ isobath. It is remarkable that essentially the same outline, including some of the detailed structure of the shelf-edge front. can be readily identified in the sun-glitter pattern in one of the shuttle photographs. In Fig. I b the oval-shaped area of the top of the bank is outlined in a broad area of diffuse, and therefore relatively dark, sun glitter. In the shuttle photograph taken a few seconds earlier (Fig. la), the viewing angle was such that the surface waters over the bank reflected the sunlight more directly, and the cold water outline of the bank is much less detailed.

Immediately before the shuttle passage, a National Oceanographic and Atmospheric Administration (NOAA) meteorological buoy located near the $100 \mathrm{~m}$ isobath south of Georges Bank (Fig. 2) recorded air/sea temperatures of $17.0 / 17.3^{\circ} \mathrm{C}$ and light winds from the north $\left(3.3 \mathrm{~m} \mathrm{~s}^{-1}\right)$. It is therefore likely that the atmospheric boundary layer was more stable over the cooler bank waters than over the warmer shelf waters offshore, for the reason given earlier. Thus it may be inferred that the cold waters atop the bank are revealed in the sun-glitter pattern because of reduced surface roughness there compared to the surrounding areas. The cool water atop Georges Bank is also associated with high concentrations of phytoplankton pigments, as shown for example in Coastal Zone Color Scanner (CZCS) images of the region (Yentsch, 1986), and the high organic content of the surface waters may have added to the suppression of the surface roughness over the bank.

Both the infrared image and the shuttle photographs reveal an irregular set of cool water extrusions or tendrils projecting seaward into the shelf water on the Atlantic side of the bank. The implied water movements indicate an exchange between the water atop the bank and the shelf waters offshore. Such exchanges affect the residence time of water on the bank and are important to questions related to larval fish stocks, dissolved nutrients and pollutant dispersal on the bank.

Exchanges between bank-top water and shelf water are associated with baroclinic instabilities of the tidal front on the Atlantic side of the bank, and also with the perturbing influence of warm-core rings from the Gulf Stream (Csanady and Magnell, 1987). During the shuttle flight. the slope waters were being influenced by at least three rings, as shown, for example, by the NOAA "Oceanographic Analysis" chart dated August 14, 1989. The surface expression of two of the rings intersected the $200 \mathrm{~m}$ isobath. The warm waters of the inner edge of one ring appear in Fig. 3 as the lighter region southeast of Cape Cod. It appears that the streamer of cool surface water emanating from the Great South Channel was being partially entrained in the clockwise circulation of the ring.

The pattern of the cool-water extrusions along the edge of the bank is remarkably similar to the pattern of submarine canyons that indent the continental margin on the Atlantic side of the bank (Cooper et al., 1987). For example, the two-pronged extrusion near the center of the bank seems to coincide with the complex, branching topography of Lydonia, Gilbert and Oceanographer Canyons (cf. Fig. 1). The mean current flows southwestward along the Atlantic side of the bank (Butman et al., 1987), and the canyons could interrupt or modulate this flow by inducing ageostrophic currents in and over the canyons (Klinck, 1988). Similar canyon effects have been noted off Newfoundland (Huthnance, 1981; Kinsella et al., 1987) and in the Balearic Sea (La Violette, et al., 1990). The Georges Bank canyons do not penetrate inward beyond about the $100 \mathrm{~m}$ isobath (Fig. 2), but they may have influenced or organized the extrusions once they were formed through instability of the tidal front.

Nantucket Island and the Great South Channel

South of Cape Cod, the islands of Nantucket and Martha's Vineyard are easily located in the shuttle photographs by the isolated clouds which cap the islands. The shoals southeast of Nantucket Island appear as a relatively bright area in Figs. $1 \mathrm{a}$ and 3, since there is no deep, cool water available to be mixed to the surface by tidal mixing over the shoals. 


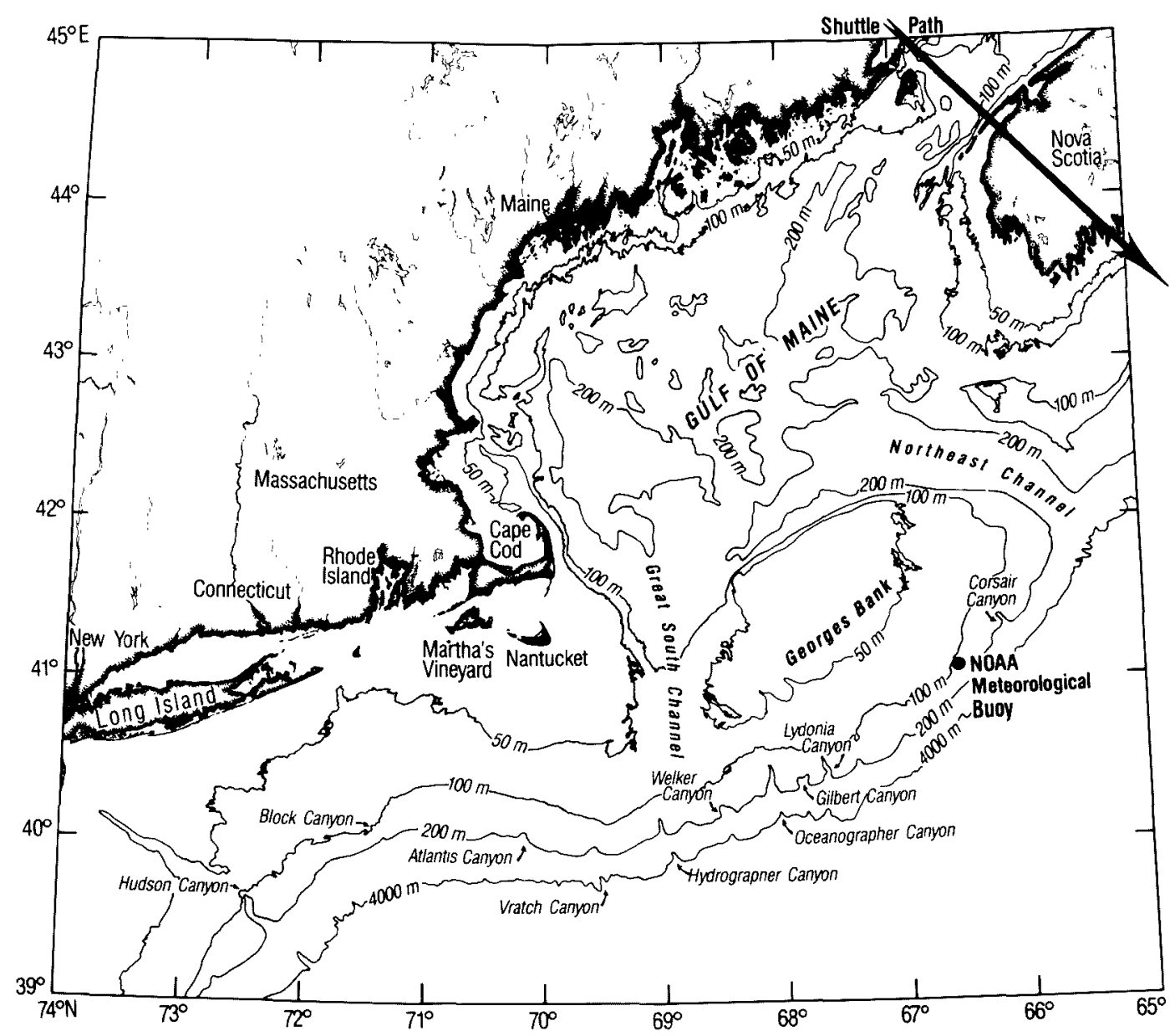

Fig. 2: Area map identifying some of the geographical features of the region covered in the shuttle photographs. The cold waters atop Georges Bank are generallyconfined to the region inside the $50 \mathrm{~m}$ isobath. where vigorous tidal stiming keeps the waters vertically mixed year-round, creating a tidal front that surrounds the bank in the summer. Over the deep basins of the Gulf of Maine in the summer, the surface waters stratify. typically producing a surface mixed layer $20-40 \mathrm{~m}$ deep and a sharp thermocline beneath. The large dot on the offshore side of the hank show's the location of a moored meteorological buoy maintained by the National Oceanic and Atmospheric Administration (NOAA). Several major canyons incising the edge of the continental slope are identified. The approximate ground track of Columbia shuttle mission STS-28 in the early afternoon of August 9.1989 is shown by the heary arrow. The photograph in Fig. Ia (p. 44) was taken when the shuttle was passing offshore of Nova Scotia, approximately above the end of the arrowhead: at the time of the photograph in Fig. $1 \mathrm{~b}(\mathrm{p} .45)$, taken a few seconds later, the shuttle was farther off shore, approximately east of Cape Cod.

The shoals surrounding Nantucket Island are outlined on their eastern flank by a streamer of cool surface water that extends from the Gult of Maine through the Great South Channel and out into the Atlantic. The outflow through the South Channel is one branch of the surface circulation in the western Gulf of Maine (Limeburner and Beardsley. 1982); the remainder of the surface flow splits into a current that feeds a narrow eastward jet along the inner edge of Georges Bank (Butman et al., 1987) and a more diffuse flow that moves northeastward inside the gulf (Brooks. 1985).

\section{The Gulf of Maine}

In the earlier of the two shuttle photographs (Fig. 1a), the sun glitter reveals several packets of internal waves propagating away from the northern edge of Georges Bank into the Gulf of Maine. In the summer months, away from the edge of the bank and the
Scotian Shelf, the interior waters of the gulf are characterized by a shallow surface layer with a thermocline at depths of 30-40 m (Flagg. 1987). Internal waves generated by horizontal tidal currents passing over the bank's steep edges propagate away from the bank into the stratified water of the gulf (Marsden, 1986). The internal wave packets seen in Fig. la evidently are made visible by modulations of the surface roughness pattern, which result in alternating bands of light (rough) and dark (smooth) surface water that travel with the waves. The banded structure arises from the convergent and divergent surface currents associated with the internal waves. A similar argument explains why internal waves are sometimes visible in synthetic-aperture radar (SAR) images of the ocean surface (Vesecky and Stewart, 1982).

The earlier shuttle photograph (Fig. 1a) clearly 


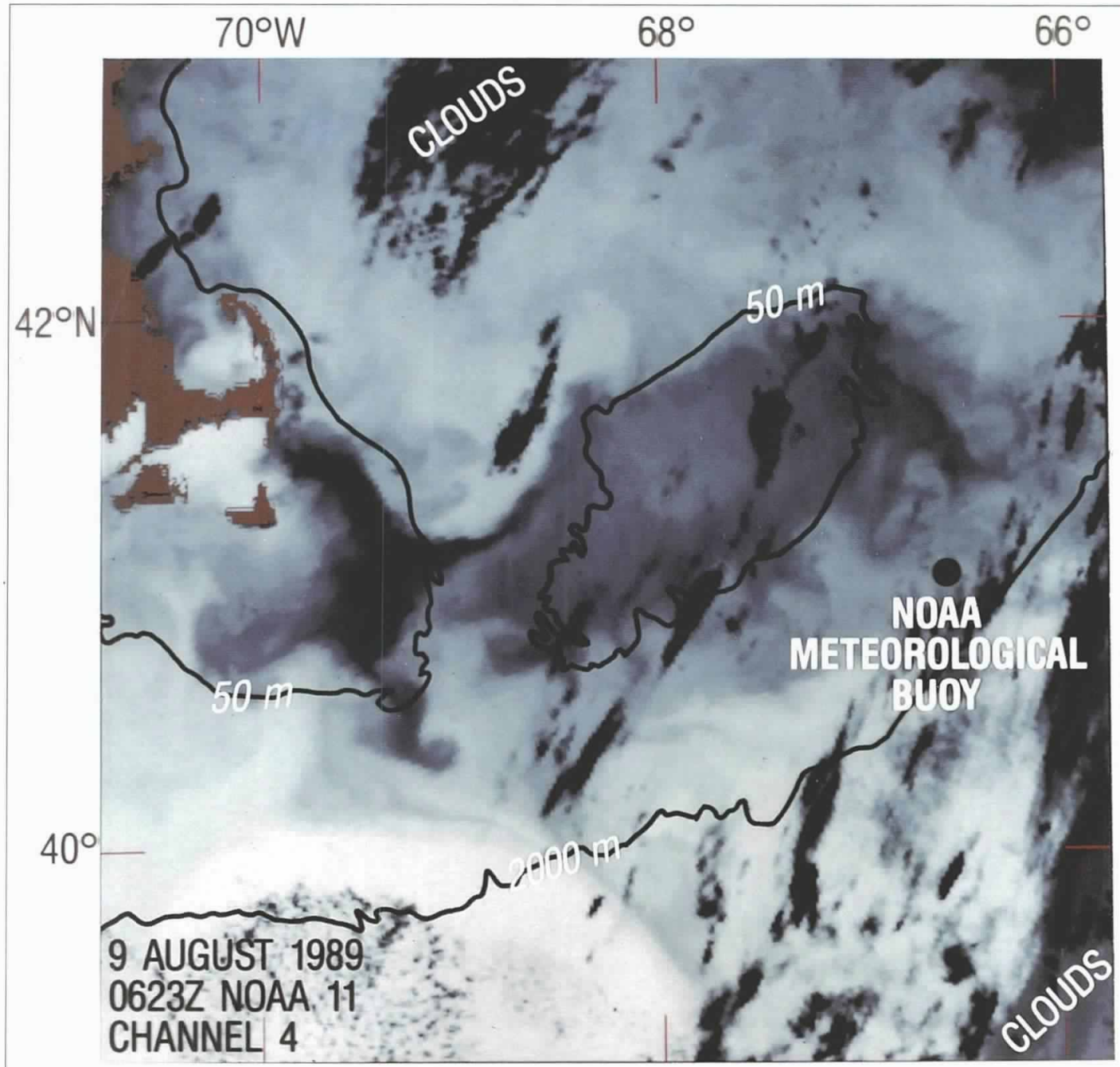

Fig. 3: An infrared image of the Georges Bank region collected on August 9, 1989, by the Advanced VeryHigh-Resolution Radiometer aboard a NOAA polar-orbiting satellite. The image reveals the sea-surface temperature distribution about thirteen hours before the shuttle photographs in Fig. 1 were taken. The cold waters over the top of the bank and southeast of Nantucket Island appear in darker blues. Relatively warm surface waters inside the Gulf of Maine and offshore in the Atlantic appear in lighter blues and near-white. The black areas show very cold cloud tops. The brown land area is the "hook" of Cape Cod, with the islands of Martha's Vineyard and Nantucket to the south. The extrusions of cold water from the south side of the bank are evident and can be compared in some detail with those seen in the visual shuttle photographs. Cool nearshore water inside the gulffeeds into an eastwardflow along the inner edge of the bank; warmer offshore waters enter the gulf through the Northeast Channel at the northeastern end of the bank; very warm waters in the inner edge of an anticyclonic (clockwise) warm-core ring entrain some of the cold, tidally-mixed waters southeast of Nantucket.

shows two packets of internal waves propagating away from the northern edge of the bank; a third, inwardmost packet is barely discernible. Another shuttle photograph in the same sequence (not shown) reveals at least four and as many as six separate packets propagating through the gulf. The curved shape of the elongated wave bands in each packet suggest that the similarly-curved northern edge of the bank is the generation zone for the waves. Each packet appears to contain four to six individual waves traveling in coherent groups, with interpacket separations of $60-70 \mathrm{~km}$. The indicated propagation speed of the semi-diurnal packets is thus about 120 $\mathrm{km} \mathrm{d}^{-1}$, or close to $1 \mathrm{~m} \mathrm{~s}^{-1}$. Within each group, crest separations are $2-5 \mathrm{~km}$, with the longest wavelengths leading the group, characteristic of dispersive wave motion. Similar features of tidally-generated internal wave packets have been noted in SAR images from other areas; for example, the Sulu Sea (Apel $e t$ al., 1985), where the packets propagate as highly non-linear internal solitons (Liu et al., 1985).

It is significant that the photographs in Fig. 1 were taken near the time of a neap tide, when tidal currents should be near their minimum values. At other times 
of the lunar cycle, the internal tidal packets should be even more prominent than those shown. It has been known for some time that internal tides are energetic in the stratified waters adjacent to the bank (Magnell et al., 1980), and more recently it has been appreciated that mixing caused by supercritical internal tides may be important in the exchange of properties between waters on the bank and in adjacent areas (Marsden, 1986; Loder et al.. 1990). Photographs from future shuttle missions may be useful in determining the prime generation regions for internal tides along the edge of the bank; they may also help identify regions where the tidal waves tend to focus and concentrate their mixing energy.

\section{Conclusions}

In this short note, we have discussed ocean phenomena revealed in the sun glitter in shuttle photographs of the Georges Bank area. The photographs indicate several physical phenomena worthy of additional study. One example is evidence for an active exchange between the waters of Georges Bank and the Atlantic slope waters to the south, a process that is well known and has received considerable attention. The photos also show, with startling clarity, internal tidal packets that are generated along the northern side of the bank and then propagate into the Gulf of Maine. Existing evidence indicates the presence of tidally-generated internal waves in the gulf, but the shuttle photographs reveal their significance in a detail not previously available.

The shuttle photographs illustrate the potential usefulness of visual imagery from low-orbit spacecraft, even when the photographic opportunities occur serendipitously. We hope to encourage future and perhaps more targeted use of shuttle photography of the ocean surface.

\section{Acknowledgements}

Paul E. La Violette and Don R. Johnson's work was sponsored by ONR program element $61153 \mathrm{~N}$ as part of NOARL Defense Sciences Research Program (NOARL Contribution VA 321:030:90). David A. Brooks' current research in the Gulf of Maine is sponsored by the National Science Foundation, grant number OCE89-14903. Approved for public release: distribution unlimited.

\section{References}

Apel. J.R., J.R. Holbrook, A.K. Liu and J.J.Tsai, 1985: The Sulu Sea internal soliton experiment. J. Phw. Occunogr. $15(12) .1625-1651$.

Arya. S.P.S. 1975: Geostrophic drag and heat transfer relations for the atmospheric boundary laver. Quart. J. Row. Me (o'or. Sor.., J1)l. 1+7-161.

Backus, R.H. 1987: Georges Bank. MIT Press. Cambridge. MA, $593 \mathrm{pp}$.

Brooks. D.A.. 1985: Vernal circulation in the Gulf of Maine. J. Goophys. Res. 90)(C5) 4687-4705.

Butman, B..J.W. Loder and R.C. Beardsley, 1987: The Seasonal Mean Circulation: Observation and Theory. In: George's Bank. R.H. Backus, ed.. MIT Press. Cambridge, MA, 593 pp.
Cooper. R.A.. P. Valentine. J.R. Uzmann and R.A. Slater. 1987: Submarine Canyons. In: Gerorges Bank. R.H. Backus, ed., MIT Press, Cambridge, MA. 593 pp.

Cox, C. and W. Munk, 1954: Measurements of the Roughness of the Sea-Surface from Photographs of the Sun Glitter.J. Opt. Soc. Am., H4, 838-850.

Csanady, G.T. and B. A. Mignell, 1987: Mixing Processes. In: Gorrges Bank. R.H. Backus. ed.. MIT Press. Cambridge. MA. 593 pp.

Flagg, C.N., 1987: Hydrographic Structure and Variability. In: Georges Bank. R.H. Backus, ed.. MIT Press. Cambridge. MA, $593 \mathrm{pp}$.

Garrett, C. 1972: Tidal resonance in the Bay of Fundy and Gulf of Maine. Nature, 238, 441-443.

Gasparovic. R. F., J. R. Apel. A. Brandt. and E. S. Kasischke. 1985: Synthetic Aperture Radar Imaging of Internal Waves. Johns Hopkins APL Tech. Digest, 6(4). 338-345.

Huthnance, J.M., 1981: Waves and currents near the continental shelf edge. Prog. Oceanog. 10. 193-226.

Kinsella, E. D., A. E. Hay, and W. W. Denner, 1987: Wind and Topographic effects on the Labrador Current at Carson Canyon. J, of Geoph. Res., 92(C/0), 10853-10869.

Klinck, J.M.. 1988: The influence of a narrow transverse canyon on initially geostrophic flow, J. Geophys. Res., 93(Cl), 509-515.

La Violette. P.E., S. Peteherych and N.F.R. Gower, 1980: Oceanographic Implications of Features in NOAA Satellite Visible Imagery. Boundary-Layer Mer., 18, 159-175

La Violette, P.E. and R.A. Arnone, 1988: A Tide-Generated Internal Waveform in the Western Approaches to the Strait of Gibraltar. J. Geophys.Res.. 93(C/2). 15653-15667.

La Violette, P.E., J. Tintore and J. Font, 1990: The Surface Circulation of the Balearic Sea.J. of Gcophlws. Res., 95. (in press).

Limeburner. R.L. and R.C. Beardsley, 1982: The seasonal hydrography and circulation over Nantucket Sloals. J. Mar. Res.. 40. 371-406.

Liu. A.K.. J.R. Holbrook and J.R. Apel, 1985: Nonlinear internal wave evolution in the Sulu Sea.I.Phys. Occanogr.. /5/12), $1613-1624$.

Loder. J.W.. 1980: Topographic rectification of tidal currents on the sides of Georges Bank. J. Phys. Oceunogr.. 10, 1399. $1+16$.

Loder. J.W.. K.F. Drinkwater and F.H. Page, 1990: Current observations at the Georges Bank tidal front . Eos. \&abstract). 71(2), 95-96.

Magnell. B.A..S.L. Spiegel. R.I.Scarlett and J.B. Andrews, 1980 The relationship of tidal and low-frequency currents on the north slope of Georges Bank. J. Phys. Occunogr.. 1048\%. $1200-1212$.

Marsden, R.F., 1986: The internal tide on Georges Bank. J. Mar Res., H. 35-50.

Osborne. A.R. and T.L. Burch. 1980: Internal solitons in the Andaman Sea. Science 208, $+51-460$.

Soules, S. D.. 1970: Sun glitter Viewed from Space. Deep-Sea Res., 17, 191-195.

Strong. A. E. and R. J. DeRycke, 1973: Ocean Current Monitoring Employing a New Satellite Sensing Technique. Science. 182, $482-484$

Vesecky, J.F. and R.H. Stewart, 1982: The observation of ocean surface phenomena using imagery from the SEASAT svinthetic aperture radar: An assessment. I. Geophys. Res. $87(C 5) .3397-3430$.

Weissman, D.E., T.W. Thompson and R. Legeckis, 1980: Modulation of sea surface radar cross section by surface stress: wind speed and temperature effects across the Gulf Stream. I Geophys. Re's. 85, 5032-50+2.

Yentsch. C.S., 1986: Enhancement of phytoplankton growth by tidal mixing June 1979. NIMBUS-7 CZCS Coastal Zome Color Scumer Imagery for selected coastal regions. Prepared under the direction of W.A. Hovis, E.F. Szajna and W.A. Bohan. NASA, Goddard Space Flight Center. p. 57 . 59.Ј 